\title{
Multiple fractures in a patient with Type 1 diabetes mellitus and coeliac disease
}

\author{
*Rajesh Joshi ${ }^{1}$, M Madvariya ${ }^{2}$ \\ Sri Lanka Journal of Child Health, 2015; 44(2): 110-111
}

(Key words: Coeliac disease, diabetes mellitus, fracture)

\section{Introduction}

The prevalence of coeliac disease (CD) in type 1 diabetes mellitus (T1DM) has been reported to be between $3-16 \%$, with a mean prevalence of $8 \%$ (5-7 times greater than the general population) ${ }^{1}$. Here we describe a child with T1DM who presented with multiple fractures and osteopenia and was discovered to have CD.

\section{Case report}

An 8 year and 8 month old girl with T1DM (diagnosed $3 \frac{1}{2}$ years back) poorly compliant to insulin and diet, presented with complaints of fever, breathlessness and abdominal pain since 2 days and frequent hypoglycaemic events since 2 years. There was a history of passing greasy stools alternating with constipation for 2 years, along with progressive abdominal distension and failure to gain adequate weight and height. On admission, the child had tachycardia, tachypnoea, pallor, cushingoid facies and dehydration. Her weight was $13.8 \mathrm{~kg}\left(<3^{\text {rd }}\right.$ centile) and her height was $105 \mathrm{~cm}\left(<3^{\text {rd }}\right.$ centile and below mid-parental height range). Hepatomegaly (6.5 $\mathrm{cm}$ below right costal margin) was noted.

On the second day of hospital stay, a pathological fracture of left lower femur was sustained with minimal handling of the leg. Radiographs revealed severe osteopenia. She also had an old partially healed right radius and left $5^{\text {th }}$ rib fracture. Skull and spine $\mathrm{x}$-rays were normal. There was no history suggestive of child abuse.

Her investigations revealed a haemoglobin level of $10.2 \mathrm{~g} \%$, a leucocyte count of 7,500/cu mm, a platelet count of 195,000/cu mm, an SGOT of 72U/L, an

\footnotetext{
${ }_{1}^{1}$ Professor, ${ }^{2}$ Registrar, Department of Paediatrics, $B$. J. Wadia Hospital for Children, Parel, Mumbai, India

*Correspondence: rrj23@rediffmail.com
}

(Received on 21 February 2014; Accepted after revision on 25 April 2014)

SGPT of $45 \mathrm{U} / \mathrm{L}$, a serum protein level of $6.9 \mathrm{~g} / \mathrm{dl}$ (serum albumin $3.2 \mathrm{~g} / \mathrm{dl}$ ), serum calcium $(\mathrm{Ca})$ of 8.6 $\mathrm{mg} / \mathrm{dl}$ with ionic $\mathrm{Ca} 1.03 \mathrm{mmol} / \mathrm{L}, \quad$ a serum phosphorus of $2.5 \mathrm{mg} / \mathrm{dl}$ (normal $3.7-5.6 \mathrm{mg} / \mathrm{dl}$ ) and an alkaline phosphatase level of $1216 \mathrm{U} / \mathrm{L}$ (normal $145-420 \mathrm{U} / \mathrm{L})$. The $25(\mathrm{OH})$ vitamin D level was $41 \mathrm{ng} / \mathrm{ml}$ (sufficient level). Bone age was $3 \frac{1}{2}$ years. $\mathrm{HbA} 1 \mathrm{C}$ was $11.7 \%$ revealing a very poor glycaemic control. Sonography of the abdomen showed hepatomegaly with bright echo-texture. Stool examination showed fat globules. Thyroid peroxidase (TPO) and tissue transglutaminase antibodies (tTgIgA) titres were $146.8 \mathrm{IU} / \mathrm{ml}(\mathrm{N}<5.6)$ and 132 $\mathrm{AU} / \mathrm{ml}(\mathrm{Neg}<8)$ respectively. Thyroid functions and lipid profile were normal. The patient refused intestinal biopsy.

She was diagnosed as having T1DM with multiple fractures (osteopenic bones), coeliac disease, autoimmune thyroiditis and Mauriac syndrome (short stature, hepatomegaly and cushingoid facies in poorly insulinized diabetics). She received basal bolus insulin therapy (regular and insulin glargine) and was supplemented with calcium, multivitamins and iron. Gluten free diet was also started.

\section{Discussion}

Based on literature, CD in T1DM is reported as silent in approximately half the cases ${ }^{1}$. Among extraintestinal manifestations, the most frequent are short stature and iron-deficiency anaemia, seen in approximately $50 \%$ of cases $^{2,3}$. Other rarer manifestations of CD in T1DM are a reduced BMI, diminished bone mass (osteopenia), bleeding due to vitamin $\mathrm{K}$ deficiency, delayed puberty, raised levels of transaminases and hypoglycaemic episodes ${ }^{1}$.

Metabolic bone disease is a less common manifestation of $\mathrm{CD}$ associated with a spectrum of musculoskeletal signs and symptoms like bone pains, proximal muscle weakness, osteopenia, osteoporosis, and fractures, reported mostly in adults. A metaanalysis by Olmos et al. with 20,955 coeliac patients, predominantly adults, showed that patients with coeliac disease have an increased fracture risk (a 
hazard ratio of 1.43 or $43 \%$ increased risk) when compared to age-matched healthy populations ${ }^{4}$. This is thought to be due to lack of absorption of vitamin $\mathrm{D}$ and calcium causing a secondary hyperparathyroidism ${ }^{5}$. However, our patient had adequate vitamin D levels. In experimental models gut inflammation is shown to activate inflammatory cytokines that are members of the TNF-alpha family called receptor activator of nuclear factor kappa $\mathrm{B}$ (RANK) and its ligand (RANK-L).This causes osteoclast activation and bone resorption. Gut inflammation also has a direct inhibitory effect on the usual inhibitor of this pathway, osteoprotegrin (OPG). Through this RANK/RANK-L/OPG pathway gut inflammation can have a direct negative effect on bone mineral density (BMD) that is independent of vitamin $\mathrm{D}$ absorption and could explain the degree of low BMD out of proportion to vitamin D levels ${ }^{5,6}$. Clinical observation indicates that clustering of three autoimmune diseases (T1DM, CD and thyroiditis) significantly increases the occurrence of osteopenia $(37.5 \%)^{5}$.

Though CD has been associated with decreased bone mineral density (BMD) in adolescents and children in various studies, ${ }^{7}$, isolated presentation as multiple fractures in patients with CD has been reported in adults and there are scarce case reports in children ${ }^{8,9}$. A study of $C D$ from India $(n=825)$ showed that 4 patients $(0.6 \%)$ had fragility fractures without any gastrointestinal manifestation. All these patients were adults except an adolescent male aged 14 years. None of them had T1DM ${ }^{9}$.

\section{References}

1. Volta U, Tovoli F, Caio G. Clinical and immunological features of coeliac disease in patients with Type 1 diabetes mellitus. Expert Review of Gastroenterology and Hepatology 2011; 5(4):479-87.

http://dx.doi.org/10.1586/egh.11.38

PMid:21780895

2. Troncone R. Auricchio S. Coeliac disease. In: Wyllie R, Hyams JS, editors, Paediatric Gastrointestinal and Liver Diseases. Philadelphia: WB Saunders Company; 1999. pp. 306-14.
3. Bhadada SK, Kochhar R, Bhansali A et al. Prevalence of clinical profile of coeliac disease in Type 1 diabetes mellitus in North India. Journal of Gastroenterology and Hepatology 2011; 26(2): 378-81. http://dx.doi.org/10.1111/j.14401746.2010.0650 8.X PMid:21261730

4. Olmos M, Antelo M, et al. Systemic review and meta-analysis of observational studies on the prevalence of fractures in coeliac disease. Digestive and Liver Disease 2008; 40:46-53. http://dx.doi.org/10.1016/j.dld.2007.09.006 PMid:18006396

5. Stanzi A, Trinti B. Risk of osteoporosis in endocrine disorders and coeliac disease. Ann Ist Super Sanita. 2007; 43(4):430-3.

6. Tilg H, Moschen AR, Kaser A, et al. Gut, inflammation and osteoporosis: basic and clinical concepts. Gut 2008; 57:684-94. http://dx.doi.org/10.1136/gut.2006.117382 PMid:18408105

7. Sud S, Marcon M, Assor E, Palmert MR, Daneman D, Mahmud FH. Coeliac disease and paediatric Type 1 diabetes: Diagnostic and treatment dilemmas. International Journal of Pediatric Endocrinology 2010; Volume 2010, Article ID 161285. Available from: http://www.ncbi.nlm.nih.gov/pmc/articles/PMC2 905696/

http://dx.doi.org/10.1155/2010/161285

PMid:20652072

8. Mulder C.M, Cardile MP, Dickert J. Coeliac disease presenting as severe osteopenia. Hawaii Medical Journal 2011; 70(11): 242-4. PMid:22162604

9. Rastogi A, Sanjay K, Bhadada SK, Santosh R. Coeliac disease: A missed cause of metabolic bone disease Indian Journal of Endocrinology and Metabolism 2012; 16(5): 780-5. http://dx.doi.org/10.4103/2230-8210.100674 PMid:23087864 